\title{
Biodata Penulis
}

Ali Maksum, adalah dosen di Jurusan Ilmu Hubungan Internasional, FISIPOL Universitas Muhammadiyah Yogyakarta (UMY) dan Magister Ilmu Hubungan Internasional, Program Pascasarjana UMY. Menyelesaikan S1 bidang Ilmu Administrasi Publik di Universitas Hang Tuah Surabaya (2006), S2 bidang Ilmu Hubungan Internasional di Universiti Malaysia Sabah (2011) dan S3 bidang Ilmu Hubungan Internasional di Universiti Sains Malaysia (2016). Tulisannya pernah dimuat di berbagai media, jurnal, dan seminar baik nasional maupun internasional (scopus). Pernah menjadi peneliti pada Japan-Related Research Project The Sumitomo Foundation Japan (2015-2016). Saat ini terlibat penelitian kerjasama dengan Kementerian Luar Negeri Republik Indonesia. Untuk tujuan akademik bisa dihubungi melalui email: amaksum@gmail.com

Anggaunitakiranantika, adalah dosen pada Jurusan Sosiologi, Fakultas Ilmu Sosial, Universitas Negeri Malang sejak tahun 2010. Menyelesaikan S1 pada Jurusan Sosiologi dan S2 Sosiologi di Universitas Airlangga Surabaya. Tertarik pada kajian tentang sosiologi gender dan keluarga, serta sosiologi industri. Selain itu, aktif terlibat dalam pemberdayaan masyarakat dan pembangunan masyarakat di Jawa Timur.

Jusmalia Oktaviani, adalah dosen Universitas Jenderal Ahmad Yani, Cimahi. Menyelesaikan S1 pada Jurusan Hubungan Internasional FISIP Universitas Mulawarman Samarinda tahun 2010. Kemudian melanjutkan S2 pada Program Pascasarjana Ilmu Hubungan Internasional FISIP Universitas Gadjah Mada (UGM) pada konsentrasi Global Humanitarian Diplomacy, dan lulus tahun 2015.

Luluk Dwi Kumalasari, adalah dosen Program Studi Sosiologi FISIP Universitas Muhammadiyah Malang (UMM). Menyelesaikan S1 pada Jurusan Sosiologi UMM tahun 1999 dan S2 pada Program Magister Sosiologi Universitas Indonesia Jakarta tahun 2004. Tertarik pada kajian sosiologi pembangunan, sosiologi budaya, serta sosiologi pariwisata. 
Oman Sukmana, merupakan dosen pada Program Studi Ilmu Kesejahteraan Sosial FISIP Universitas Muhammadiyah Malang (UMM). Menempuh pendidikan S-1 Jurusan Ilmu Kesejahteraan Sosial, FISIP Universitas Padjajaran (Unpad) Bandung, lulus tahun 1991; S-2 Psikologi Bidang Kajian Utama (BKU) Psikologi Sosial pada Program Pascasarjana Unpad, lulus tahun 1997; dan S-3 Sosiologi di Fisipol Universitas Gadjah Mada (UGM), lulus tahun 2016. Pada tahun 2013 mengikuti Sandwich Programs pada Departement of Sociology and Anthropology, Faculty of Social and Behavioral Sciences, Leiden University of Netherlands. Saat ini menjabat sebagai Ketua Ikatan Pendidikan Pekerjaan Sosial Indonesia (IPPSI) untuk periode 2016-2018, dan Ketua Asosiasi Prodi Ilmu Kesejahteraan Sosial Perguruan Tinggi Muhammadiyah untuk periode 2017-2021. Aktif menulis buku dan bahan ajar, kegiatan penelitian baik internal maupun eksternal, dan melaksanakan berbagai pengabdian pada masyarakat.

Riady Ibnu Khaldun, adalah dosen pada Program Studi Ilmu Pemerintahan Fakultas Ilmu Sosial dan Ilmu Politik, Universitas Tadulako. Menyelesaikan S1 Ilmu Hubungan Internasional di President University. Kemudian melanjutkan ke jenjang S2 Ilmu Hubungan Internasional di Universitas Gadjah Mada (UGM). Saat ini tercatat sebagai mahasiswa S3 pada Program Doktor Ilmu Ekonomi Universitas Tadulako. Dapat dihubungi melalui email riadyibnukhaldun@rocketmail.com

Rizki Rahmadini Nurika, menyelesaikan studi S1 di Program Studi Ilmu Hubungan Internasional Universitas Airlangga, Surabaya, dan studi S2 di Program Pascasarjana Ilmu Hubungan Internasional Universitas Gadjah Mada, Yogyakarta, pada konsentrasi Global Trade Diplomacy. Rizki memiliki dedikasi yang tinggi di dunia pendidikan karena ia berkomitmen untuk selalu mengamalkan ilmu yang telah ia peroleh selama ini. Saat ini, Rizki tengah aktif bekerja sebagai dosen di Program Studi Hubungan Internasional Universitas Islam Negeri Sunan Ampel, Surabaya. Selain senang mengajar, Rizki juga senang membuat tulisan-tulisan untuk diterbitkan atau dipresentasikan di acara konferensi internasional.

Saiman, adalah dosen di Fakultas Ilmu Sosial dan Ilmu Politik (FISIP) Universitas Muhammadiyah Malang sejak tahun 1991. Menyelesaikan S1 di Jurusan Hubungan 
Internasional tahun 1990 dan S2 bidang Administrasi Pembangunan dan Lingkungan di Universitas Hasanuddin Makassar. Adapun S3 Ilmu Politik diselesaikan di Universitas Indonesia Jakarta. Pengalaman organisasi profesi antara lain sebagai anggota Asosiasi Ilmu Politik Indonesia (AIPI) Pusat Jakarta 2011-2013 serta anggota Bidang Kerjasama dan Kelembagaan Asosiasi Dosen Ilmu Politik (ADIPI) Pusat Jakarta tahun 2013-2017.

Verdinand Robertua, is a professional in International Relation with expertise in International Political Economy. He did undergraduate at International Relations Department in Universitas Indonesia with specialization in international human rights policies. He received his MA with specialization in European Union from Linköping Universitet in Linköping, Sweden. Currently, he is pursuing his Ph.D in Universitas Padjajaran, Bandung. Prior to MA scholarship in Sweden, he joined global PR firm Edelman as consultant in Public Affairs. In Edelman, he provided communication and strategic analysis to many corporations in various industries, including public service sectors. Now he is working for Center for Security and Foreign Affairs (CESFAS) as head of Foreign Affairs department. In CESFAS, he is responsible to conduct some research and publication programme in some key areas including ASEAN Economic Community. He is also a research fellow in Marthinus Academy.

Winda Hardyanti, dosen yang mengabdi di Prodi Ilmu Komunikasi FISIP Universitas Muhammadiyah Malang sejak tahun 2010. Tahun 2008, lulus dari program sarjana Jurusan Ilmu Komunikasi Universitas Airlangga dan S2 di Magister Sosiologi konsentrasi Sosiologi Komunikasi UMM tahun 2013. Kecintaannya pada dunia tulis menulis dan jurnalistik membawanya berkarir sebagai reporter radio selama dua tahun di Radio Trijaya FM Surabaya dan freelance journalist di Majalah Gapura milik Pemkot Surabaya selama delapan tahun. Dapat dihubungi melalui email winda86@gmail.com 